\title{
A cultural landscape approach to community-based conservation in Solomon Islands
}

\author{
Richard K. Walter ${ }^{1}$ and Richard J. Hamilton ${ }^{2,3}$
}

\begin{abstract}
International environmental organizations have an increasing commitment to the development of conservation programs in high-diversity regions where indigenous communities maintain customary rights to their lands and seas. A major challenge that these programs face is the alignment of international conservation values with those of the indigenous communities whose cooperation and support are vital. International environmental organizations are focused on biodiversity conservation, but local communities often have a different range of concerns and interests, only some of which relate to biodiversity. One solution to this problem involves adoption of a cultural landscape approach as the ethical and organizational foundation of the conservation program. In our conservation work in coastal Melanesia, we have developed a cultural landscape approach that involves the construction of a conceptual model of environment that reflects the indigenous perceptions of landscape. This model incorporates cultural, ideational, and spiritual values alongside other ecosystem services and underpins the conservation activities, priorities, and organizational structure of our programs. This cultural landscape model was a reaction to a survey of environmental values conducted by our team in which Solomon Islanders reported far greater interest in conserving cultural heritage sites than any other ecosystem resources. This caused a radical rethinking of community-based conservation programs. The methodologies we adopted are derived from the fields of archaeology and historical anthropology, in which there is an established practice of working through research problems within the framework of indigenous concepts of, and relationship to, landscape. In our work in Isabel Province, Solomon Islands, coastal communities have enthusiastically adopted conservation programs that are based on cultural landscape models that recognize indigenous values. A particularly useful tool is the Cultural Heritage Module, which identifies cultural heritage sites that become targets of conservation management and that are used as part of a holistic framework for thinking about broader conservation values.
\end{abstract}

Key Words: archaeology; biodiversity; climate change; Coral Triangle; heritage; Solomon Islands

\section{INTRODUCTION}

Over the last few decades there has been an increasing conservation investment in high-biodiversity regions where indigenous communities retain customary tenure over the conservation resource (Klein et al. 2010, Bowler et al. 2012). In these situations it is not uncommon for international environmental agencies to find themselves in partnership with communities who do not necessarily share the same conservation values, which can affect the long-term viability of their programs. One such location is Solomon Islands, where biodiversity-focused nongovernment organizations (NGOs) such as The Nature Conservancy (TNC) and the Word Wildlife Fund (WWF) have operated for more than 20 years. Although these NGOs have had successes (Weeks et al. 2014), a reoccurring struggle for them has been harmonizing their organizational values with those of the indigenous communities who own the lands and seas that the NGOs wish to see protected. Although the conservation NGOs recognize the need to incorporate people into conservation agendas, their overarching mandate is the protection of natural resources. Conservationists will point out to communities that establishing networks of protected areas act as "insurance policies" that will ensure food security, prosperity, and enhanced social and ecological resilience to climate change into the future. However, this ideology is not always shared by indigenous Solomon Islanders. Rather, some individuals perceive international conservation NGOs as primarily being the distributers of short-term funds that can be engaged with opportunistically to bring immediate benefits to their community (Hviding 2003).
The short-term funding cycles of donor agencies, payment for ecosystem services schemes, and the wealth discrepancies between "fly in fly out" foreign conservationists and rural Solomon Islanders often perpetuate this perception, and communities can end up being angry that the benefits they had anticipated from engaging in conservation were not forthcoming (Foale 2001). Such scenarios can even lead to "conservation blackmail" (Van Helden 1998), whereby communities threaten to destroy a resource of high biodiversity value if they are not compensated. A highly publicized recent example was the slaughter of nearly a thousand dolphins in January 2013 by villagers in South Malaita, Solomon Islands. This community has hunted dolphins on a small scale for hundreds of years, mainly so they can use the teeth in the manufacture of the local ceremonial currency (Tapaleao 2013). In 2011 they signed an agreement with a California-based NGO agreeing to forego their traditional hunting practices if the NGO provided significant funding over two years for the development of village projects. Mismanagement of funds resulted in only a proportion of the payments flowing to Malaita, and some factions reacted by hunting dolphins on an unprecedented scale.

Even when NGOs are successful in portraying their core values and limitations to communities, an undesirable consequence can be that they are taken far less seriously than they would have hoped, with some community members concluding that environmental NGOs have relatively little to offer in terms of addressing their immediate health, development, and day-to-day survival needs. Anthropologist Edvard Hviding, who has worked 
extensively in Solomon Islands sums up this position: "...the champions of international biodiversity conservation are not necessarily the agents whose messages have the strongest resonance among the villagers still in control of the resources that constitute biodiversity" (Hviding 2003:551). A pressing issue for the environmental NGOs is how to generate greater support and interest for their efforts without overselling the direct benefits of biodiversity conservation or attempting to play the role of humanitarian NGOs.

The key issue that creates a divide between biodiversity NGOs and rural Solomon Islanders is the fact that indigenous communities tend to embrace a more complex and diverse set of environmental values than is often appreciated. It is not necessarily difficult to develop programs that recognize community subsistence needs. For example, many regional conservation efforts emphasize the value of establishing protected areas to ensure food security and to provide a buffer against climate change (Cabral et al. 2013). In Polynesia, environmental agencies sometimes promote conservation by invoking the concept known in the New Zealand Maori language as rahui. Rahui is a form of traditional prohibition that effectively conserves a resource for a determined period and thus can serve as a conservation tool (Wheen and Ruru 2011). It is much more difficult, however, to develop conservation programs that account for environmental value systems that relate to matters such as ideology, power networks, and notions of identity. What NGOs often misunderstand is that these values associated with landscape frequently turn out to be just as compelling in terms of determining behavior within, and attitudes toward, the environment as economic imperatives. In fact, the interplay between intangible values and physical needs determines the way indigenous partner communities will prioritize conservation goals and set agendas to meet them.

Our contention is that if biodiversity NGOs working in nonWestern contexts assist with conserving both cultural and physical resources, then there will be significantly more support for their agendas, without any compromise to their core objectives. We refer to this conservation strategy as a cultural landscape approach, and draw on our experiences in Solomon Islands to describe how such an approach can be rolled out.

\section{A CULTURAL LANDSCAPE APPROACH}

The term "cultural landscape" carries a range of meanings. In cultural ecology, it often refers to a geographic area "... in which the relationships between human activity and the environment have created ... patterns and feedback mechanisms that govern the presence, distribution and abundance of species assemblages" (Farina 2000:320). This definition is relevant to our use of the term, but somewhat narrow. Cultural ecology tends to treat environment and culture dichotomously, thus downplaying the importance of the two-way dialogue between them (Balée 1998). Plieninger and Bieling (2012) have recently expanded the notion of cultural landscapes as places where complex interactions occur between ideas, social structures, and physical features. Their approach recognizes the historical and cultural dimensions of landscape, but their interests and those of their colleagues are primarily ecological and have to do with management. Our interest is in the social domain and in understanding the influence of landscape on the cultural, political, and ideological world of those who inhabit it.

Cosgrove (1998, 2003) describes two discourses around landscape: an ecological one and a semiotic one. The latter is concerned with the "...context and processes through which cultural meanings are invested into and shape a world" (Cosgrove 2003:15). In our Solomon Islands work we are concerned with both discourses, and we draw heavily from ideas in archaeology, which is a field that has developed a strong dialogue between them.

Since the 1980s anthropologists and archaeologists have become increasingly interested in the interconnectedness between the material and ideological dimensions of landscape (Hodder 1987, Gledhill et al. 1988, Bender 1992, Tilley 1994, 2010, Tilley and Bennett 2004). One particular approach that has relevance for working with indigenous communities involves the concept of landscapes as palimpsests of history. This is the idea that landscapes accumulate the physical relics and memories of the actions of ancestors and ancestral beings (Sheppard et al. 2002, Thomas 2012) and that these associations can be drawn on in the construction of social identity, in the encoding of cultural memories and history, and in debates on legitimacy and social order (Ashmore and Knapp 1999). It is possible to conceptualize landscape as a text on which the history of a people is inscribed and that can be used structurally as part of the process of socialization and social reproduction (Aston 1985, Ashmore and Knapp 1999). This concept is very appropriate in coastal Melanesia.

In Solomon Islands, White (1991) describes the way in which tribal history is entangled in the shrines and sacred sites scattered through the rain forests of Santa Isabel. As an Isabel islander walks through the forest, moving between named sites and places, history is revealed and the journey helps structure or reinforce individual and group identity. This is not just an interesting abstract notion; it plays a pivotal role in determining the actions and decision making of Isabel communities in relation to their environment. Another example is from Roviana Lagoon in the Solomon Islands' Western Province. There, the small island of Nusa Roviana was a central place for the head-hunting cults that dominated the social, ideological, and economic life of the Western Province into the early 20th century (Sheppard et al. 2000, Walter and Sheppard 2001, Walter et al. 2004). Today the material remains of that history can be encountered in the form of shrines, stone terraces, and platforms scattered through the forests and mangrove shorelines of the island and adjacent mainland. These archaeological remains are more than the static remnants of history. They are part of the lived world of the Roviana people and are vital in their everyday social negotiations. Today these places and the stories associated with them are used to convey land use rights for descent groups and revenue from international fisheries and logging ventures, and they help determine how power is distributed within communities and passed intergenerationally. The tribal histories gathered in the Roviana landscape also remain the wellspring of identity and personhood (Thomas et al. 2001). It is the recognition of the embedded nature of the relationship between the cultural and physical domains of landscape that distinguishes our cultural landscape approach. 


\section{WHY ARCHAEOLOGY IS USEFUL IN CONSERVATION}

Archaeology is, by definition, the study of a nonrenewable resource. Thus, most archaeologists are involved to some extent with heritage conservation work. However, we are interested in the deeper theoretical and methodological aspects of archaeology that make that discipline useful in environmental conservation programs, especially those involving partnership with indigenous communities. Three particular features of archaeological practice are relevant to this issue.

The first feature is archaeology's special relationship to anthropology, its parent discipline. Anthropology is the social science most directly concerned with understanding the unique values and ideals of different cultural groups, with particular historical emphasis on non-Western ones. It is also a discipline built on the foundation of participant observation, i.e., the concept of working directly with indigenous societies under their own terms and preferably in the local language.

The second feature is derived from archaeology's materialist perspective. Archaeologists are deeply interested in the way people physically engage with the world around them; how they move through, exploit and modify land; how they transform natural objects into tools; and how they obtain, process, and discard resources. Although the questions archaeologists ask fall into the domain of human culture and history, archaeologists are used to addressing these questions through the methods of hard science. They routinely work with environmental scientists, geologists, and materials scientists, and much of their theory is derived from the field of ecology.

The third feature is the archaeological focus on time, the centrality of history, and most importantly, the constancy of change. Archaeologists are especially resistant to problematic essentialist views of indigenous societies that see them as changeless. This is the idea that the indigenous world is populated by "people without history," societies whose lives in the past were much the same as at the time of their first Western encounter (Wolf 1982). Below we outline several specific ways in which an archaeological perspective can contribute to conservation programs involving partnerships with indigenous communities.

\section{Appreciating the anthropogenic nature of landscapes}

Within Western popular imagination there is a view of indigenous societies, particularly those dwelling in forests and riverine settings, as living in equilibrium with their landscapes; they are often imagined to occupy small, dispersed settlements and to have had a low long-term impact on their environment. This view is erroneous; archaeology has shown that wherever people have lived for any period of time they have left a mark on their landscape and most "lived environments" are, to a greater or lesser extent, anthropogenic. In Solomon Islands, Hviding and Bayliss-Smith (2000) have shown that the primordial and largely uninhabited rainforests of New Georgia are strongly anthropogenic, having passed through many cycles of clearance, modification, and disturbance by generations of horticulturalists and hunters. Even in Brazilian Amazonia, long imagined as the embodiment of the pristine natural world, the evolution of forest ecosystems and soils is the history of human-biological interactions (Heckenberger et al. 2007). Any ecosystem model that includes humans must be based on a realistic understanding of how humans have interacted with landscapes over the long-term. This is hindered by what the archaeologist Bruce Trigger calls the "flat view of native history" that prevails in much discourse about indigenous societies. The flat view is the idea that "...prehistoric times were not qualitatively different from the ethnographic present" (Trigger 1989:125). Indigenous societies experience change as Western societies do, and it is only through the application of the historical sciences, particularly archaeology, that the complex, long-term nature of human-environmental interactions becomes evident.

\section{Establishing baseline information on ecology, and mapping} changes in human-environmental systems

There is a need in conservation and management to establish ecological baseline information or reference conditions (Pandolfi et al. 2003, Thurstan et al. 2010). There is value too in understanding "the long-term dynamic change in coupled human-environment systems" (Heckenberger et al. 2007:200). One way of achieving these aims is through the application of methods involving "... the use of historic and prehistoric data (e.g., paleobiological, archeological, historical) to understand ancient and modern ecosystems, often with the goal of providing context for contemporary conservation" (Rick and Lockwood 2013:3). Written records have proven to be extremely valuable when they can supplement archaeological data to provide information on past ecosystems (e.g., Jackson et al. 2001, Newsome et al. 2007). In non-Western settings, where documentary records are frequently unavailable, ethnographic methods can be used to pick up short-term changes (Johannes et al. 2000, Hamilton et al. 2012). However, the major avenue for exploring long-term cultural-environmental dynamics is archaeology. For example, in tropical Polynesia, where written records rarely extend more than a few centuries, archaeology has become the lead discipline in understanding prehuman baseline ecologies, as well as in recording change following human arrival (e.g., Smith 2005). The essential information on the Polynesian avifaunal record, for example, including the modes and rate of change in populations and taxonomic diversity following human colonization, has been provided by archaeology (Weisler and Gargett 1993, Steadman 1995, Weisler 1995, Holdaway and Jacomb 2000, Steadman 2006).

\section{Understanding the nature of human response to ecological change}

Understanding how societies respond to environmental change is vital in the development of contingency planning for both catastrophic events and measured environmental change. Climate change is a particularly topical example. Although scientists can model the impact of climate change on biological systems, human response and reaction are conditioned by cultural variables. Unless there is a good understanding of how human societies at similar organizational levels and in similar ecosystems have responded to climate change in the past, it will be difficult to model future responses and thus develop viable management plans. As it turns out, the best body of evidence concerning the impact of climate change on human societies comes directly from archaeology (e.g., An et al. 2005, Lape 2007, Cooper and Peros 2010, Pringle and Kerr 2012). A recurring message from such studies is that although it is possible to identify general trends, human response is largely contingent on the local cultural and historical situation. Thus, there is value in including an archaeological perspective to obtain basic data on previous impact-response events. 


\section{METHODS}

\section{Environmental setting of Solomon Islands}

Solomon Islands (Fig. 1) has a land mass of $30,000 \mathrm{~km}^{2}$ and a population of approximately 500,000 (Solomon Island Government 2010). The United Nations classifies Solomon Islands as a "least developed nation," with the majority of people living in coastal villages, practicing a subsistence lifestyle, and retaining customary ownership of their land and shallow seas. Despite its small size, Solomon Islands has high biological and cultural diversity (Olson and Dinerstein 1998, Veron et al. 2009, Kool et al. 2010). The high biodiversity of Solomon Islands has attracted many international conservation NGOs, with TNC, WWF, Conservation International, and WorldFish all operating in the country over the past three decades. As a signatory to the Convention of Biological Diversity (Lipsett-Moore et al. 2010), Solomon Islands is committed to ensuring that at least $17 \%$ of its terrestrial areas and $10 \%$ of its coastal and marine areas are conserved through representative and well-connected systems of protected areas. However, less than $1 \%$ of Solomon Islands' land and seas are currently so protected (Peterson et al. 2012). Most existing protected areas encompass shallow marine habitats that are managed by local communities with support from NGOs or government. Major threats to the biodiversity of Solomon Islands include logging, commercial inshore fishing, industrial agriculture such as oil palm production, and mining (Peterson et al. 2012). With the imminent exhaustion of loggable forests, mining is seen by many as the solution for economic development in Solomon Islands (Roughan and Wara 2010). These threats are compounded by a rapidly expanding human population and the impacts of climate change.

Fig. 1. Map of the Pacific showing the location of the Solomon Islands and key areas mentioned in the text.

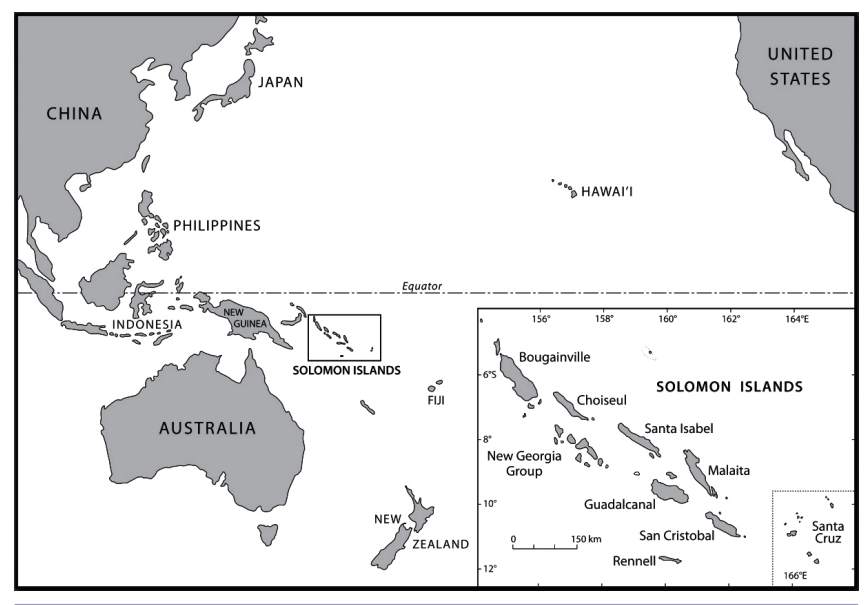

The cultural heritage dimension of Solomon Islands landscapes There have been many biological and ecological surveys of Solomon Islands biodiversity, and the main ecosystems of the terrestrial and marine zones are well described (Olson and Dinerstein 1998, Green et al. 2006, Kool et al. 2010). To provide context for the discussion of our case study, we review here the cultural dimension of Solomon Islands landscapes with an emphasis on the archaeological record or the cultural heritage sites. The best-known archaeological record of Solomon Islands is from the Western Province, and this provides a reasonable model for the rest of Solomon Islands. The visible archaeological record of the Western Province consists largely of stone-faced terraces, platforms, and walls representing earlier village sites, agricultural complexes, and shrines. Shrines are common in many parts of Solomon Islands, and in the Western Province they consist of stone or coral-faced platforms and walled compounds with ancillary structures that include uprights, table or altar stones, and skull houses (Fig. 2; Sheppard et al. 2000, Thomas et al. 2001, Walter and Sheppard 2001). Shrines often contain human skulls and artifacts as votive offerings. Shrine sites are associated with ancestor cults, which developed over the last 1000 years and persisted well into the 20th century (Walter and Sheppard 2006, 2009). In parts of Solomon Islands ancestral sites are collectively referred to as kastom sites in the local Pijin vernacular.

Fig. 2. A small ancestral skull shrine located in Roviana Lagoon, New Georgia, Western province. Photographed by R. Walter in 1996.

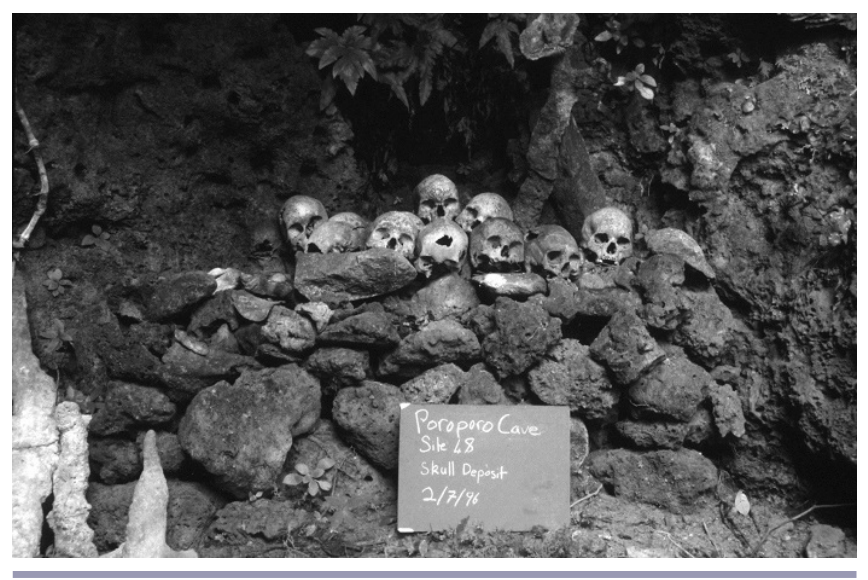

Although associated with cults and ceremonies that are no longer extant, many kastom sites are associated with named ancestors and still carry rich meaning for communities. These sites are imbued with power, or tambu, and are thus potentially dangerous. Other sites are recognized as places used and lived in by ancestors, or by tribes who have subsequently moved on, to be succeeded on the land by the current occupants. Some sites have passed out of the consciousness of contemporary communities; they are recognized as cultural but are not strictly kastom sites. In addition to the tangible sites, there are many kastom sites that do not contain physical signs of human modification but are nevertheless meaningful in much the same way.

Kastom sites are actively drawn into many aspects of village social, political, and economic life. As physical markers of history and ancestral relationships, they are used as referents in matters of social identity and political legitimacy. They are intimately connected with land and sea tenure, and the use and redistribution of resources. Kastom sites are used in negotiations over mining and forestry concessions, and royalty payments from foreignowned companies. In times of tension, kastom sites take on new meanings as places from which power might be drawn or that can create dangers to the community. Political and religious leaders, and potential leaders, use kastom sites to enhance their power and 
influence, and to deny that of rivals (White 1979, 1991, Thomas 2003).

\section{SOLOMON ISLANDS CASE STUDY}

We first used elements of a cultural landscape approach to conservation on a trial basis in 2011, working in Solomon Islands villages that were already involved in biodiversity projects with TNC. Our aim was to incorporate cultural heritage into the conservation work for two reasons: first to improve the levels of acceptance of the biodiversity program and second to create a program that was considered useful and meaningful to the local communities in terms of their own indigenous values. The cultural landscape approach we adopted involved a three-stage approach.

\section{Stage 1: developing the cultural landscape framework}

The aim of Stage 1 was to build up a sound basic understanding of the cultural landscape of the community: what cultural sites were present on the landscape, how they were valued, and what role they played in community life. The cultural heritage work was led by Richard Walter and Solomon Islands archaeologist Oswald Alesasa, and was carried out in local languages or Solomon Islands pijin.

A first objective was to "develop a definition of cultural heritage sites within the group that was consistent with international heritage models while embracing indigenous values and concepts" (Walter 2011:2). This was achieved through village meetings and workshops, and through informal conversation with village leaders. The next step was to understand what types of cultural heritage resources were present in the community territories through a combination of structured dialogue and field surveys. The aim was not to gather site information to take away, but rather to enable the community to think in a structured way about their heritage resource. This exercise involved the participants visiting examples of their kastom sites, as well as the archaeologists pointing out and explaining archaeological sites that were not currently within the kastom site category. This process of dialogue and fieldwork resulted in a deeper understanding for all parties about the meaning, value, and role of cultural heritage sites both locally and within the context of archaeological values and thought. Having built up an understanding of the nature of the cultural heritage record, the community participants discussed the role of these places within the community.

\section{Stage 2: running a Cultural Heritage Module (CHM)}

Having developed an overview of the cultural heritage landscape, we used a CHM designed by Richard Walter as a tool for integration into future conservation programs. The CHM took the form of a series of four-day workshops teaching basic field skills for the recording and management of kastom sites. The $\mathrm{CHM}$ was designed to allow communities to develop their own systems for cultural heritage management that could be integrated with larger conservation initiatives. It had two premises: (1) the starting point for any conservation or protection program must be the construction of a quality knowledge base and (2) although Solomon Islands communities will support some level of provincial and national government management of natural resources, such support will not be extended to management of kastom sites that have immediate and exclusive cultural, spiritual, and political value to the communities involved. Therefore, any conservation and management program would have to be entirely community based.

\section{Stage 3: integrating cultural heritage into a provincial protected} area network

Building on the experiences of Stages 1 and 2, in 2012 TNC worked with multiple landowners and the Isabel provincial government to develop a stakeholder-driven Ridges to Reefs conservation plan for Isabel Province (Peterson et al. 2012). The planning process consisted of a series of workshops that were attended by 118 stakeholders. The Isabel Council of Chiefs and Isabel Provincial Government identified which stakeholders to invite, with care being taken to ensure that each of the eight districts of Isabel were represented. Stakeholders included chiefs, church leaders, politicians, women, youth, and industry partners. Many of the stakeholders attended all three workshops. Participants' travel, accommodation, and food costs were covered by TNC (Peterson et al. 2012). As a first step, workshop participants listed all the landscape features that they recognized as providing an ecosystem service to the community. This was carried out in a context that was consistent with the cultural landscape approach in that it included provision for cultural services along with other ecosystem service classes. This exercise resulted in the identification of 87 distinct components of landscape, including kastom sites that were recognized as providing an ecosystem service and being of conservation significance. We refer to these as ecosystem resources.

Workshop participants then broke into three groups based on their region. Each group was provided with a key for the 87 ecosystem resources and large color base maps at 1:70,000 scale showing their customary estates with terrestrial and reef data, rivers, roads, and villages. Participants then used their local knowledge to mark the location of the ecosystem resources within their customary lands and seas (Fig. 3). In a sense, this involved the construction of a cultural landscape map. Participants were then asked to plan out a conservation program. They first determined what percentage of the ecosystem resources they would like to see conserved across Isabel Province by assigning a low and high value to each ecosystem resource, reflecting the range of views held by the participants as to its value.

Fig. 3. Participants in the "Ridges to Reefs" conservation planning workshop, Kia, Santa Isabel, Solomon Islands, March 2012. (Photo: Nate Peterson).

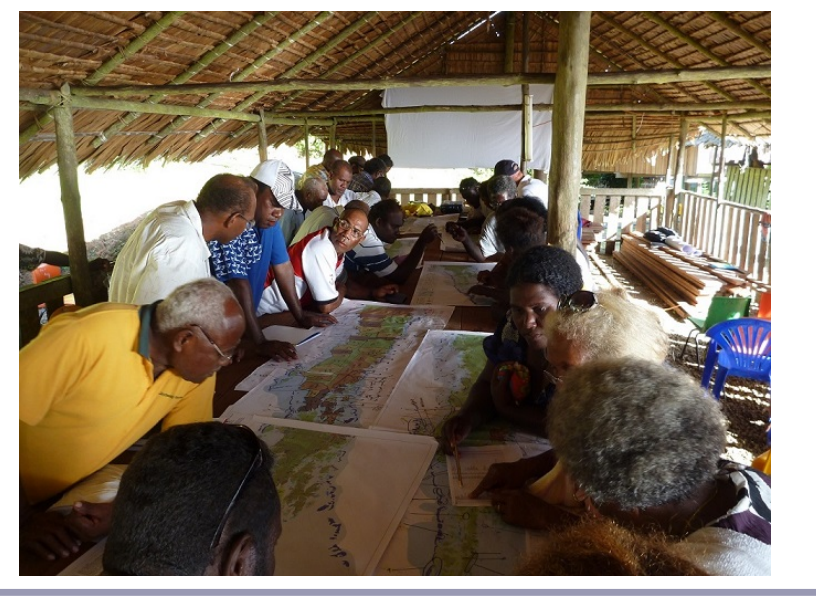




\section{RESULTS}

Stage 1: developing the cultural landscape framework

Table 1 lists the various roles played by cultural heritage sites as reported in the CHMs. All these were considered important enough to warrant the implementation of active management measures. Table 1 also displays the main factors that Solomon Islands informants perceived to be threatening to their cultural heritage resources.

Table 1. Values and roles of cultural heritage (kastom) sites and their potential threats as reported by Solomon Island participants in the Cultural Heritage Workshops run under the Cultural Heritage Module (CHM).

\begin{tabular}{ll}
\hline \hline $\begin{array}{l}\text { Value and role of cultural } \\
\text { heritage sites }\end{array}$ & $\begin{array}{l}\text { Currently perceived threats to } \\
\text { cultural heritage sites }\end{array}$ \\
\hline $\begin{array}{l}\text { Resolution of land disputes } \\
\text { Inheritance of political office }\end{array}$ & $\begin{array}{l}\text { Climate change and sea level rise } \\
\text { Logging, mining, and other } \\
\text { development activities }\end{array}$ \\
$\begin{array}{l}\text { Negotiation of royalty payments } \\
\text { (mining, forestry, etc.) }\end{array}$ & $\begin{array}{l}\text { Stealing of votive offerings for sale } \\
\text { on antiquities market }\end{array}$ \\
$\begin{array}{l}\text { Intergenerational transmission of } \\
\text { historical knowledge } \\
\text { shrines by rival tribes to enhance }\end{array}$ \\
$\begin{array}{l}\text { Personal and social identity } \\
\text { Potential value in cultural } \\
\text { tourism ventures }\end{array}$ & $\begin{array}{l}\text { Destruction by Christian cults } \\
\text { Tourism (collecting of relics) }\end{array}$ \\
$\begin{array}{l}\text { Building community knowledge } \\
\text { of environment and history }\end{array}$ & $\begin{array}{l}\text { Removing skulls for magic } \\
\text { Education of youth }\end{array}$ \\
& $\begin{array}{l}\text { Expansion of village gardens } \\
\text { Looting of shrines to acquire } \\
\text { goods for use in traditional }\end{array}$ \\
& $\begin{array}{l}\text { exchange systems (marriage } \\
\text { payments etc.) }\end{array}$ \\
\hline
\end{tabular}

\section{Stage 2: running a Cultural Heritage Module}

Much of the four days of workshop time was spent teaching essential archaeological field skills required to develop and manage an inventory of kastom sites, including reconnaissance and recording survey, mapping, and photography (Fig. 4). The last sessions were committed to discussing ideas raised during the workshop sessions, looking at options for developing local conservation and protection programs, or for integrating such programs into ongoing conservation initiatives. The participants organized additional sessions to discuss ideas for establishing structures and protocols for site recording and protection. These involved the discussion of complex and contentious political and historical issues and took place in the local languages without the presence of the workshop organizers.

\section{Stage 3: integrating cultural heritage into a provincial protected area network}

To the surprise of the TNC team, kastom sites were the only resource that was unanimously ranked with a value of $100 \%$ in the survey of ecosystem resources. None of the other ecosystem resources were assigned a conservation priority higher than $50 \%$, which has obvious implications for planning community-based conservation in Isabel Province. After the workshops, the base maps that had local features added to them were digitized to create Geographic Information Systems (GIS) files. The software called
Marxan was then used to assist with designing a series of maps showing what an Isabel Ridges to Reefs Protected Area Network could look like under a range of low-high conservation scenarios (Peterson et al.2012). Marxan is a decision support tool developed specifically to assist with complex conservation planning problems (Possingham et al. 2000). Because cultural heritage targets were set at $100 \%$, the Marxan software set conservation priorities that captured varying percentages of natural resource targets and all of the cultural heritage targets identified by Isabel stakeholders that had clear and discrete spatial referents. It did not account for the multitude of landscape features that either were unable to be spatially identified for cultural reasons or did not have a clear spatial reference, e.g., the wandering tracks of souls passing to the afterlife. The challenge for us as conservation planners is to develop models of landscape that as closely as possible approximate those of the Isabel communities with whom we work. Marxan software helps, but it must be supplemented by grounded, community-led ethnographic and historical research.

Fig. 4. Participants in the Sukikki Cultural Heritage Workshop recording a cultural heritage site. Guadalcanal, Solomon Islands, November 2012.

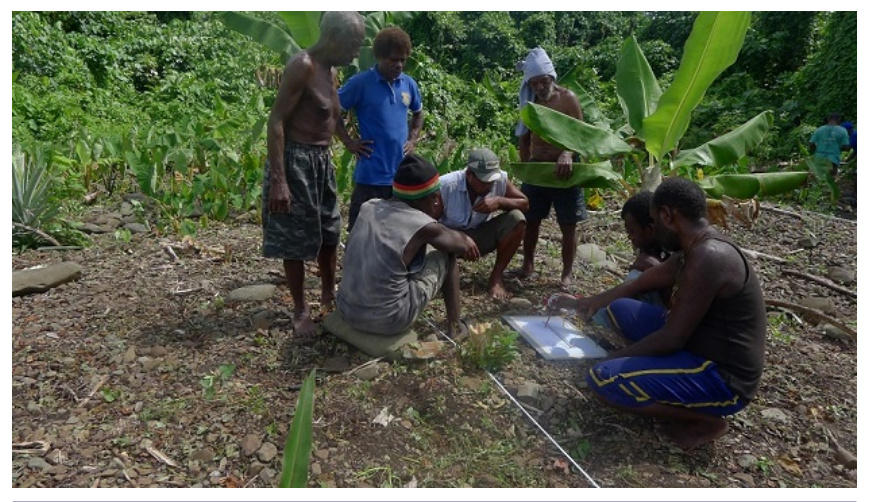

\section{Events following the development of the Isabel Ridges to Reefs} Plan

In late 2012 the Mothers Union, a not-for-profit organization with widespread networks throughout Isabel Province, raised awareness of the Isabel Ridges to Reefs Plan in more than 40 communities. They stressed the integrated nature of the program and the importance of including a cultural heritage dimension. This resulted in a groundswell of interest in community-based conservation and sustainable resource management. By January 2013 the Environmental Community Conservation officer in Isabel had received nine written requests from communities seeking assistance with developing managed areas. Each request stressed the desire to include both cultural and biological targets. TNC with the Isabel Provincial government are adopting a crossdisciplinary approach to respond to these requests. The Isabel Environmental Coordinator is now working alongside the Isabel Province Tourism and Cultural Unit to develop community-based resource management plans that protect both cultural and biological features of significance. An ongoing component of building this holistic program involves running additional $\mathrm{CHMs}$, during which local participants are trained in the methodologies for identifying, documenting, and conserving cultural heritage 
sites. It is envisaged that cultural and biological features of high value will eventually become formally protected by inclusion of community-based resource management plans under the Solomon Islands 2010 Protected Areas Act.

\section{DISCUSSION}

The cultural landscape conservation approach we developed in the Solomon Islands has received high levels of community acceptance. It was designed to accommodate community values alongside those of the agencies that fund natural resource management and has three key features:

- It organizes community-based conservation programs around the framework of a conceptual model of landscape that embraces the values of local partner communities.

- It draws heavily on methodologies from archaeology, an anthropological field discipline with established practices of engaging with indigenous concepts of, and relationships to, landscape and history.

- It expands the scope of conservation initiatives to include cultural heritage along with biodiversity targets.

As our Solomon Islands case studies have shown, cultural, ideological, and spiritual values are key drivers in structuring the relationship between a society and the environment in which its members live out their lives. This is as true in Western urban settings as it is in the forests of Amazonia. Conservation and environmental managers have long recognized the need to account for the ideological realm in their planning, and various paradigms have been developed. The Ecosystem Services framework that was adopted by the Millennium Ecosystem Assessment Board of the United Nations is now the most influential paradigm within the international conservation movement. The Ecosystem Services framework recognizes four essential classes of service that ecosystems contribute to the wellbeing of communities (Millennium Ecosystem Assessment 2005). One of these is cultural services (CS), which encompass, among other things, the contribution of aesthetic and spiritual values that ecosystems provide for community comfort and security.

There has been much discussion about the value of including CS values in community-based conservation programs and a general consensus that such inclusion is worthwhile. The arguments in favor of inclusion can be summarized in terms of two overlapping themes. First, there is an ethical concern that conservation efforts should address the needs of indigenous stakeholder communities, rather than simply encourage those communities to become the custodians of pristine ecosystems to satisfy the environmental aspirations of the developed world. Second, there is a pragmatic recognition that the inclusion of CS will strengthen other conservation initiatives. The problem, however, is that CS is difficult to measure and quantify, and thus difficult to represent empirically in decision making (Daniel et al. 2012). Most attempts to measure CS values have relied on the application of some type of economic model (see review in Sander and Haight 2012), but these largely fail to recognize fundamental differences between cultural values and those associated with the other ecosystem service classes (Chan et al. 2012, Norton et al. 2012). For example, some conservation programs recognize the concept of sacred sites, but frequently the value of including such places in conservation programs is linked to the spin-off effects in promoting biodiversity rather than to their service role to the wider community (Metcalfe et al. 2010, Rutte 2011, Shen et al. 2012). In general, the successful incorporation of CS into environmental planning programs is heavily biased toward problems for which the planner and the target communities share the same basic principles of value and environmental philosophies, and for which some sort of financial substitution schema is appropriate (e.g., Martin-Lopez et al. 2009, Gee and Burkhard 2010, Junge et al. 2011, Norton et al. 2012, Sander and Haight 2012). Outside of these settings there is a tendency for "...non-use, intangible, and cultural values [to be] relegated to an after-thought or poorly represented by ill-suited value metrics..." (Chan et al. 2012:10). This is especially likely in community-level projects with a large disjunction between the cultural systems and values of the conservation professionals and those of the local people. Such scenarios are common in highbiodiversity regions such as island Melanesia and Amazonia, which attract considerable investments from agencies who often work closely with indigenous communities (Game et al. 2011).

The development of the CHM and inclusion of cultural sites in the Solomon Islands conservation programs described in this paper was a response to a perceived problem in gaining long-term community buy-in to biodiversity-focused agendas. Having worked with Solomon Islands communities on cultural projects for several decades, we saw the potential value of this approach, but our view was not generally shared by conservation practitioners. Securing funding to enable us to incorporate cultural heritage work proved challenging, with cultural heritage components frequently dropped from grant proposals. Some environmentalists viewed the inclusion of cultural heritage as "mission drift," i.e., an interesting idea but something that had little direct relevance to biodiversity. Nevertheless in 2011 TNC received funds from Australian Aid to run a program to build the resilience of communities and their ecosystems to the impacts of climate change in the Pacific and a component that addressed the impacts of climate change on cultural heritage sites was accepted.

The turnaround for us in convincing our environmental colleagues of the value of this approach was the dramatic outcome of Stage 3 of our program, when Isabel Island communities gave their cultural heritage sites top ranking for conservation attention, far above any other ecosystem resource. This reinforced the importance of understanding that there may be significant disjunctions between the conservation values of NGOs and those of the indigenous communities with whom they work. It also provided support for our claim that the most effective way of gaining strong community support for conservation efforts is not by convincing Isabel islanders of the value of biodiversity, but by co-opting their values into the program, including a cultural heritage component. This position was further reinforced by follow-up work in the Isabel community.

Setting up a conservation program in a high-biodiversity zone where indigenous communities maintain rights over the conservation resource involves a large investment and potential risks. We suggest that risk can be reduced at little extra cost by adopting a cultural landscape approach. As our Solomon Islands case study has shown, a cultural landscape approach can generate considerable support for the environmental objectivities of NGOs. Beyond these practical considerations, however, we further suggest that conservation practitioners working in 
indigenous settings have an ethical responsibility to recognize and respect the landscape values of the custodians of those places, regardless of whether these values fall outside their core biodiversity business.

Responses to this article can be read online at: http://www.ecologyandsociety.org/issues/responses. $\mathrm{php} / 6646$

\begin{abstract}
Acknowledgments:
ACKNOWLEDGEMENTS This study was completed with support from an Australian Aid funded community based adaptation project led by The Nature Conservancy. We would like to thank our field collaborators Willie Atu, John Pita, and Oswald Alesasa for their support in the Solomon Islands. Les O'Neil produced the illustrations and Robyn James and Meg Ryan provided logistical support. We also acknowledge the cooperation of the Arnavons Community Marine Protected Area committee and the Sukiki community on Guadlcanal. Eddie Game, Emma Brooks, and Christopher Jacomb provided useful comments on drafts of this paper.
\end{abstract}

\section{LITERATURE CITED}

An, C. B., L. Y. Tang, L. Barton, and F. H. Chen. 2005. Climate change and cultural response around $4000 \mathrm{cal}$ yr B.P. in the western part of Chinese Loess Plateau. Quaternary Research 63:347-352. http://dx.doi.org/10.1016/j.yqres.2005.02.004

Ashmore, W., and A. B. Knapp. 1999. Archaeologies of landscape: contemporary perspectives. Blackwell, Malden, Massachusetts, USA.

Aston, M. 1985. Interpreting the landscape: landscape archaeology in local studies. B.T. Batsford, London, UK.

Balée, W. L. 1998. Advances in historical ecology. The historical ecology series. Columbia University Press, New York, New York, USA.

Bender, B. 1992. Theorising landscapes, and the prehistoric landscapes of Stonehenge. Man 27:735-755. http://dx.doi. org/10.2307/2804172

Bowler, D. E., L. M. Buyung-Ali, J. R. Healey, J. P. G. Jones, T. M. Knight, and A. S. Pullin. 2012. Does community forest management provide global environmental benefits and improve local welfare? Frontiers in Ecology and Environment 10(1):29-36. http://dx.doi.org/10.1890/110040

Cabral, R., A. Cruz-Trinidad, R. Geronimo, L. Napitupulu, P. Lokani, D. Boso, C. M. Casal, N. A. Fatan, and P. Aliño. 2013. Crisis sentinel indicators: averting a potential meltdown in the Coral Triangle. Marine Policy 39:241-247. http://dx.doi. org/10.1016/j.marpol.2012.10.012

Chan, K. M. A., T. Satterfield, and J. Goldstein. 2012. Rethinking ecosystem services to better address and navigate cultural values. Ecological Economics 74:8-18. http://dx.doi.org/10.1016/j. ecolecon.2011.11.011
Cooper, J., and M. Peros. 2010. The archaeology of climate change in the Caribbean. Journal of Archaeological Science 37:1226-1232. http://dx.doi.org/10.1016/j.jas.2009.12.022

Cosgrove, D. E. 1998. Social formation and symbolic landscape. University of Wisconsin Press, Madison, Wisconsin, USA.

Cosgrove, D. 2003. Landscape: ecology and semiosis. Pages 15-21 in H. Palang and G. Fry, editors. Landscape interfaces: cultural heritage in changing landscapes. Springer Netherlands, Dordrecht, The Netherlands. http://dx.doi.org/10.1007/978-94-017-0189-1 2

Daniel, T. C., A. Muhar, A. Arnberger, O. Aznar, J. W. Boyd, K. M. A. Chan, R. Costanza, T. Elmqvist, C. G. Flint, P. H. Gobster, A. Grêt-Regamey, R. Lave, S. Muhar, M. Penker, R. G. Ribe, T. Schauppenlehner, T. Sikor, I. Soloviy, M. Spierenburg, K. Taczanowska, J. Tam, and A. von der Dunk. 2012. Contributions of cultural services to the ecosystem services agenda. Proceedings of the National Academy of Sciences of the United States of America 109:8812-8819. http://dx.doi.org/10.1073/pnas.1114773109

Farina, A. 2000. The cultural landscape as a model for the integration of ecology and economics. Bioscience 50:313-320. http://dx.doi.org/10.1641/0006-3568(2000)050[0313:TCLAAM]2.3. $\mathrm{CO} ; 2$

Foale, S. 2001. Where's our development? Landowner aspirations and environmentalist agendas in Western Solomon Islands. Asia Pacific Journal of Anthropology 2:44-67. http://dx.doi. org/10.1080/14442210110001706105

Game, E. T., G. Lipsett-Moore, R. Hamilton, N. Peterson, J. Kereseka, W. Atu, M. Watts, and H. Possingham. 2011. Informed opportunism for conservation planning in the Solomon Islands. Conservation Letters 4:38-46. http://dx.doi.org/10.1111/ j.1755-263X.2010.00140.X

Gee, K., and B. Burkhard. 2010. Cultural ecosystem services in the context of offshore wind farming: a case study from the west coast of Schleswig-Holstein. Ecological Complexity 7:349-358. http://dx.doi.org/10.1016/j.ecocom.2010.02.008

Gledhill, J., B. Bender, and M. T. Larsen, editors. 1988. State and society: the emergence and development of social hierarchy and political centralization. Unwin Hyman, London, UK.

Green, A., P. Lokani, W. Atu, P. Ramohia, P. Thomas, and J. Almany. 2006. Solomon Islands marine assessment. Technical report of survey conducted May 13 to June 17, 2004. The Nature Conservancy, Brisbane, Queensland, Australia.

Hamilton, R., Y. Sadovy de Mitcheson, and A. Aguilar-Perera. 2012. The role of local ecological knowledge in the conservation and management of reef fish spawning aggregations. Pages 331-370 in Y. Sadovy de Mitcheson and P. L. Colin, editors. Reef fish spawning aggregations: biology, research and management. Springer Science+Business Media, New York, New York, USA.

Heckenberger, M. J., J. C. Russell, J. R. Toney, and M. J. Schmidt. 2007. The legacy of cultural landscapes in the Brazilian Amazon: implications for biodiversity. Philosophical Transactions of the Royal Society B Biological Sciences 362:197-208. http://dx.doi. org/10.1098/rstb.2006.1979 
Hodder, I. 1987. Converging traditions: the search for symbolic meanings in archaeology and geography. Pages 134-145 in M. J. Wagstaff, editor. Landscape and culture: geographical and archaeological perspectives. Blackwell, New York, New York, USA.

Holdaway, R. N., and C. Jacomb. 2000. Rapid extinction of the moas (Aves: Dinorinthiformes): model, test, and implications. Science 287:2250-2254. http://dx.doi.org/10.1126/science.287.5461.2250

Hviding, E. 2003. Contested rainforests, NGOs, and projects of desire in Solomon Islands. International Social Science Journal 55:539-554. http://dx.doi.org/10.1111/j.0020-8701.2003.05504003. $\underline{\mathrm{X}}$

Hviding, E., and T. Bayliss-Smith. 2000. Islands of rainforest: agroforestry, logging and eco-tourism in Solomon Islands. Ashgate, Farnham, UK.

Jackson, J. B. C., M. X. Kirby, W. H. Berger, K. A. Bjorndal, L. W. Botsford, B. J. Bourque, R. H. Bradbury, R. Cooke, J. Erlandson, J. A. Estes, T. P. Hughes, S. Kidwell, C. B. Lange, H. S. Lenihan, J. M. Pandolfi, C. H. Peterson, R. S. Steneck, M. J. Tegner, and R. R. Warner. 2001. Historical overfishing and the recent collapse of coastal ecosystems. Science 293:629-638. http:// dx.doi.org/10.1126/science.1059199

Johannes, R. E., M. R. Freeman, and R. J. Hamilton. 2000. Ignore fishers' knowledge and miss the boat. Fish and Fisheries $1: 257-271$.

Junge, X., P. Lindemann-Matthies, M. Hunziker, and B. Schüpbach. 2011. Aesthetic preferences of non-farmers and farmers for different land-use types and proportions of ecological compensation areas in the Swiss lowlands. Biological Conservation 144:1430-1440. http://dx.doi.org/10.1016/j.

biocon.2011.01.012

Klein, C. J., N. C. Ban, B. S. Halpern, M. Beger, E. T. Game, H. S. Grantham, A. Green, T. J. Klein, S. Kininmonth, E. Treml, K. Wilson, and H. P. Possingham. 2010. Prioritizing land and sea conservation investments to protect coral reefs. PLOS ONE 5(8): e12431. http://dx.doi.org/10.1371/journal.pone.0012431

Kool, J., T. Brewer, M. Mills, and R. Pressey. 2010. Ridges to reefs conservation plan for Solomon Islands. ARC Centre of Excellence for Coral Reef Studies, James Cook University, Townsville, Queensland, Australia.

Lape, P. V. 2007. Climate change and archaeology in the Pacific. Archaeology in Oceania 42:81-81. http://dx.doi.org/10.1002/ j.1834-4453.2007.tb00020.x

Lipsett-Moore, G., R. Hamilton, N. Peterson, E. Game, W. Atu, J. Kereseka, J. Pita, P. Ramohia, and C. Siota. 2010. Ridges to reefs conservation plan for Choiseul Province, Solomon Islands. The Nature Conservancy, Asia-Pacific Resource Centre, Brisbane, Queensland, Australia.

Martin-Lopez, B., E. Gómez-Baggethun, P. L. Lomas, and C. Montes. 2009. Effects of spatial and temporal scales on cultural services valuation. Journal of Environmental Management 90:1050-1059. http://dx.doi.org/10.1016/j.jenvman.2008.03.013

Metcalfe, K., R. Ffrench-Constant, and I. Gordon. 2010. Sacred sites as hotspots for biodiversity: the Three Sisters Cave complex in coastal Kenya. Oryx 44:118-123. http://dx.doi.org/10.1017/ $\underline{\mathrm{S} 0030605309990731}$
Millennium Ecosystem Assessment. 2005. Ecosystems and human well-being: synthesis. Island Press, Washington, D.C., USA.

Newsome, S. D., M. A. Etnier, D. Gifford-Gonzalez, D. L. Phillips, M. van Tuinen, E. A. Hadly, D. P. Costa, D. J. Kennett, T. P. Guilderson, and P. L. Koch. 2007. The shifting baseline of northern fur seal ecology in the northeast Pacific Ocean. Proceedings of the National Academy of Sciences 104:9709-9714. http://dx.doi.org/10.1073/pnas.0610986104

Norton, L. R., H. Inwood, A. Crowe, and A. Baker. 2012. Trialling a method to quantify the 'cultural services' of the English landscape using Countryside Survey data. Land Use Policy 29:449-455. http://dx.doi.org/10.1016/j.landusepol.2011.09.002

Olson, D. M., and E. Dinerstein. 1998. The global 200: a representation approach to conserving the Earth's most biologically valuable ecoregions. Conservation Biology 12:502-515. http://dx.doi.org/10.1046/j.1523-1739.1998.012003502.x

Pandolfi, J. M., R. H. Bradbury, E. Sala, T. P. Hughes, K. A. Bjorndal, R. G. Cooke, D. McArdle, L. McClenachan, M. J. H. Newman, G. Paredes, R. R. Warner, and J. B. C. Jackson. 2003. Global trajectories of the long-term decline of coral reef ecosystems. Science 301:955-958. http://dx.doi.org/10.1126/ science. 1085706

Peterson, N., R. Hamilton, J. Pita, W. Atu, and R. James. 2012. Ridges to Reefs Conservation Plan for Isabel Province, Solomon Islands. The Nature Conservancy, Indo-Pacific Division, Solomon Islands, Brisbane, Queensland, Australia.

Plieninger, T., and C. Bieling, editors. 2012. Resilience and the cultural landscape: understanding and managing change in humanshaped environments. Cambridge University Press, Cambridge, UK. http://dx.doi.org/10.1017/CBO9781139107778

Possingham, H., I. Ball, and S. Andelman. 2000. Mathematical methods for identifying representative reserve networks. Pages 291-305 in S. Ferson and M. Burgman, editors. Quantitative methods for conservation biology. Springer-Verlag, New York, New York, USA. http://dx.doi.org/10.1007/0-387-22648-6 17

Pringle, H., and R. A. Kerr. 2012. Did pulses of climate change drive the rise and fall of the Maya? Science 338:730-731. http:// dx.doi.org//10.1126/science.338.6108.730

Rick, T. C., and R. Lockwood. 2013. Integrating paleobiology, archeology, and history to inform biological conservation. Conservation Biology 27:45-54. http://dx.doi.org/10.1111/ j.1523-1739.2012.01920.x

Roughan, P., and S. Wara. 2010. Solomon Islands country report for the 5-year review of the Mauritius Strategy for further implantation of the Barbados Programme of Action for Sustainable Development of SIDS (MSI+5). United Nations General Assembly, New York, New York, USA.

Rutte, C. 2011. The sacred commons: conflicts and solutions of resource management in sacred natural sites. Biological Conservation 144:2387-2394. http://dx.doi.org/10.1016/j.

biocon.2011.06.017

Sander, H. A., and R. G. Haight. 2012. Estimating the economic value of cultural ecosystem services in an urbanizing area using hedonic pricing. Journal of Environmental Management 113:194-205. http://dx.doi.org/10.1016/j.jenvman.2012.08.031 
Shen, X., Z. Lu, S. Li, and N. Chen. 2012. Tibetan sacred sites: understanding the traditional management system and its role in modern conservation. Ecology and Society 17(2): 13. http://dx. doi.org/10.5751/ES-04785-170213

Sheppard, P., S. Aswani, R. Walter, and T. Nagaoka. 2002. Cultural sediment: the nature of a cultural landscape in Roviana Lagoon. Pages 35-61 in T. Ladefoged and M. W. Graves, editors. Pacific landscapes: archaeological approaches. Easter Island Foundation, Bearsville, Honolulu, Hawaii, USA.

Sheppard, P., R. Walter, and T. Nagaoka. 2000. The archaeology of head-hunting in Roviana Lagoon. Journal of the Polynesian Society 109:9-37.

Smith, I. 2005. Retreat and resilience: fur seals and human settlement in New Zealand. Pages 6-18 in G. G. Monks, editor. Exploitation and cultural importance of sea mammals. Oxbow, Oxford, UK.

Solomon Islands Government. 2010. Report on 2009 population and housing census. Basic tables and census description. Solomon Islands Government Statistical Bulletin. Government Printer, Honiara, Guadalcanal, Solomon Islands.

Steadman, D. W. 1995. Prehistoric extinctions of Pacific Island birds: biodiversity meets zooarchaeology. Science 267:1123-1130. http://dx.doi.org/10.1126/science.267.5201.1123

Steadman, D. W. 2006. Extinction and biogeography of tropical Pacific birds. University of Chicago Press, Chicago, Illinois, USA.

Tapaleao, V. 2013. Dolphins killed in pay spat. New Zealand Herald, 25 January.

Thomas, J. 2012. Archaeologies of place and landscape. Pages 167-187 in I. Hodder, editor. Archaeological theory today. Polity, Cambridge, UK.

Thomas, T. 2003. Things of Roviana. Material culture, personhood and agency in nineteenth century Solomon Islands. Dissertation. University of Otago, Dunedin, New Zealand.

Thomas, T., P. S. Walter, and R. Walter. 2001. Landscape, violence and social bodies: ritualized architecture in a Solomon Islands society. Journal of the Royal Anthropological Institute 7:545-572. http://dx.doi.org/10.1111/1467-9655.00077

Thurstan, R. H., S. Brockington, and C. M. Roberts. 2010. The effects of 118 years of industrial fishing on UK bottom trawl fisheries. Nature Communications 1:15. http://dx.doi.org/10.1038/ $\underline{\text { ncomms } 1013}$

Tilley, C. Y. 1994. A phenomenology of landscape: places, paths, and monuments. Berg, Oxford, UK.

Tilley, C. Y. 2010. Interpreting landscapes: geologies, topographies, identities. Left Coast, Walnut Creek, California, USA.

Tilley, C. Y., and W. Bennett. 2004. The materiality of stone. Berg, Oxford, UK.

Trigger, B. G. 1989. A history of archaeological thought. Cambridge University Press, Cambridge, UK.

Van Helden, F. 1998. Between cash and conviction. The social context of the Bismark-Ramu integrated conservation and development project. Monograph 33. Papua New Guinea National Research Institute, Waigani, Papua New Guinea.
Veron, J. E. N., L. M. Devantier, E. Turak, A. L. Green, S. Kininmonth, M. Stafford-Smith, and N. Peterson. 2009. Delineating the Coral Triangle. Galaxea, Journal of Coral Reef Studies 11:91-100. http://dx.doi.org/10.3755/galaxea.11.91

Walter, R. 2011. Report on cultural heritage module of building the resilience of communities and their ecosystems to the impacts of climate change in the pacific programme. University of Otago, Dunedin, New Zealand.

Walter, R., and P. Sheppard. 2001. Nusa Roviana: the archaeology of a Melanesian chiefdom. Journal of Field Archaeology 27:295-318. http://dx.doi.org/10.1179/jfa.2000.27.3.295

Walter, R., and P. Sheppard. 2006. Archaeology in Melanesia: a case study from the Western Province of the Solomon Islands. Pages 137-159 in I. Lilley, editor. Archaeology of Oceania: Austalia and the Pacific Islands. Blackwell, London, UK. http://dx.doi. org/10.1002/9780470773475.ch7

Walter, R., and P. Sheppard. 2009. A review of Solomon Island archaeology. Pages 35-72 in P. Sheppard, T. Thomas, and G. Summerhayes, editors. Lapita, ancestors and descendants. New Zealand Archaeological Association, Auckland, New Zealand.

Walter, R., T. Thomas, and P. Sheppard. 2004. Cult assemblages and ritual practice in Roviana Lagoon, Solomon Islands. World Archaeology 36:142-157. http://dx.doi.org/10.1080/0043824042000192614

Weeks, R., P. M. Aliño, S. Atkinson, P. Belida II, A. Binson, W. L. Campos, R. Djohani, A. L. Green, R. Hamilton, V. Horigue, R. Jumin, K. Kalim, A. Kasasaiah, J. Kereseka, C. Klein, L. Laroya, S. Magupin, B. Masike, C. Mohan, R. M. Da Silva Pinto, A. Vave-Karamui, C. Villanoy, M. Welly, and A. T. White. 2014. Developing marine protected area networks in the Coral Triangle: good practices for expanding the Coral Triangle Marine Protected Area system. Coastal Management 42:183-205. http://dx.doi. org/10.1080/08920753.2014.877768

Weisler, M. I. 1995. Henderson island prehistory: colonization and extinction on a remote Polynesian island. Biological Journal of the Linnean Society 56:377-404. http://dx.doi.org/10.1111/ j.1095-8312.1995.tb01099.x

Weisler, M. I., and R. Gargett. 1993. Pacific Island avian extinctions: the taphonomy of human predation. Archaeology in Oceania 28:85-93. http://dx.doi.org/10.1002/j.1834-4453.1993. tb00319.x

Wheen, N., and Ruru, J. 2011. Providing for Rahui in the law of Aotearoa New Zealand. Journal of the Polynesian Society 120:169-182.

White, G. 1979. War, peace and piety in Santa Isabel, Solomon Islands. Pages 109-139 in M. Rodman and M. Cooper, editors. The Pacification of Melanesia. University of Michigan Press, Ann Arbor, Michigan, USA.

White, G. M. 1991. Identity through history: living stories in a Solomon Islands society. Cambridge University Press, Cambridge, UK. http://dx.doi.org/10.1017/CBO9780511621895

Wolf, E. R. 1982. Europe and the people without history. University of California Press, Berkeley, California, USA. 